\author{
Л.М.Шелюк, \\ кандидат педагогічних наук, \\ докторант НПУ імені М.П.Драгоманова
}

\title{
ОСВІТА В СИСТЕМІ ФОРМУВАННЯ ДЕМОКРАТИЧНИХ ОРІЕНТАЦЙ МОЛОДІ
}

Засвоєння демократичних цінностей може досягатися різними засобами: політико-правовими, культурно-мистецькими, економічними, морально-етичними, науково-освітніми тощо. Проте найефективнішим механізмом утвердження нової ціннісної моделі є освіта, що забезпечує перетворення зовнішніх (суспільно унормованих) світоглядних стандартів у внутрішню потребу особистості, формування світоглядних орієнтирів і переконань у процесі становлення людини як особистості. В Україні цей процес має свої особливості. Головні з них зумовлені переходом суспільства від тоталітарного типу соціальної організації до демократичного. Це означає, що стандарти і норми поведінки, властиві суспільству тоталітарного типу, мають бути замінені моделями та цінностями демократичного суспільства. При цьому найголовнішим є трансформація світогляду не стільки зрілих членів суспільства, скільки створення нових векторів у наймолодшої спільноти.

Демократизація $є$ загальною тенденцією сучасного суспільного розвитку. Вона охоплює всі сфери суспільного життя, всі соціальні прошарки, суспільні процеси і явища. Особливо це стосується вищих навчальних закладів, навчально-виховного процесу вищої школи. Демократизація освіти, виховання, життєдіяльності студентів $\epsilon$ невідворотним явищем, яке необхідно навчитись підтримувати та втілювати в життя. Демократизація є водночас і виявом, і складовою духовного збагачення суспільства, важливим чинником духовної самореалізації особистості. Саме тому дослідження впливу демократизації в українському суспільстві на формування духовних цінностей та світогляд студентської молоді є важливою теоретичною проблемою, що поєднує психологічні, філософські, педагогічні, організаційно-правові та інші складові. Тому важливо 
зробити аналіз освіти 3 погляду демократичних орієнтацій студентської молоді на стадії іiї формування.

У вищому навчальному закладі молода людина має можливість усвідомити, практично сприйняти демократичні цінності і принципи, адже вища освіта і в нашому суспільстві є середовищем потенційної реалізації демократичних принципів мислення.

Ще однією особливістю демократичних процесів,що відбуваються в молодіжному середовищі, є те, що студентство за своїми віковими, соціальними, психологічними, духовними і фізичними характеристиками є найактивнішим прошарком населення будьякої країни. Це стосується і розуміння, і реалізації демократичного стилю мислення, поведінки, управління соціальними інститутами. Актуальним стає виховання у студентів демократичних цінностей і принципів, які будуть активно втілюватися протягом усього життя.

Демократизація суспільно-політичного і громадського життя в нашій державі має ще одну особливість - це низький рівень розвитку системи громадських інституцій, які забезпечують потреби населення в громадянській освіченості. Через це більшість функцій громадянської освіти переймає на себе саме вища освіта, коли протягом університетсько-громадської активності студенту прищеплюються такі демократичні якості, як відчуття єдності, солідарності, толерантності до інших тощо.

Отже, система вищої освіти є однією з основних інституцій формування у студентів громадянських ціннісних основ, а також однією з головних особливостей впровадження демократичних тенденцій не лише в студентському середовищі, а і в інших соціальних структурах українського суспільства.

О.Невмержицький виділяє такі основні особливості і необхідні умови розгортання демократичних процесів у студентському середовищі: уникнення (відмова від) ідеологізації і нав'язування певних поглядів; формування вільного громадянина, здатного свідомо брати участь у політичному житті, зміцнювати і розвивати демократію; надання студентам можливості вибору навчальних курсів (у тому числі в інших ВН3) та викладачів; навчання студентів самостійності, надання їм максимальної свободи, виховання почуття відповідальності за свої дії, рівень і напрям підготовки; зміна ролі викладача в технології здобуття знань; використання наставників для вироблення у студентів самостійності та громадської відповідальності; 
наявність демократичної системи надання й оцінювання знань, яка стимулює студентів до постійної праці з оволодіння ними і найбільш адекватно відображає індивідуальний розвиток і здібності; контроль за якістю освіти незалежними організаціями, що проводиться як на рівні студентів, так і на рівні викладачів. вплив рекомендацій таких незалежних організацій на функціонування ВН3; використання студентського самоврядування в академічних групах та гуртожитках (тобто на рівні навчання і побуту) як одного з найважливіших щаблів громадського зростання; забезпечення рівних умов вступу до ВНЗ, навчання в ньому, а також рівних можливостей набуття подальшої освіти впродовж усього життя [1, 147].

На вибір студентською молоддю світоглядних орієнтацій впливають такі фактори: великомасштабні соціальні структури, що відбиваються у змісті і формах виховання, механізмах соціалізації; сила соціальних норм, звичаїв, мікросоціальних (регіональних, локальних) установок; соціальні лідери, «кумири», приклад осіб, які досягли певного соціального успіху; пропаганда і агітація у засобах масової інформації; ступінь відкритості суспільства, доступ до альтернативних джерел інформації; індивідуальний досвід людини, iii життєва стратегія, конкретна ситуація, що передує світоглядному вибору [2, 23].

Як відзначає Н.А.Латигіна, в епоху глобалізації будь-якому суспільству, в тому числі і українському, необхідні: система певних цілей і цінностей, які сприймає і поділяє більшість його членів, реалістична і приваблива модель майбутнього, створена на засадах традицій минулого та реалій сьогодення... Демократія - це певна система цінностей, спосіб політичного життя і мислення, що грунтується на рівності всіх перед законом і правах кожного члена суспільства на життя, свободу і приватну власність [3]. Можна навести дані соціологічного дослідження, яке проводив фонд «Демократичні ініціативи» у 2009 р. Згідно з даними цього опитування, українці включають у своє розуміння демократії ті риси, які це поняття насправді не передбачає. Так, найголовніша характеристика демократії для людей - це рівність усіх громадян перед законом (74\%). При цьому 59\% включили в поняття демократії «забезпечення права на працю». Захищеність від зловживань влади є важливою для 47\% респондентів. Особисту недоторканність громадянина віднесли до пріоритетів демократії 34\%, а ось свободу слова, 
поглядів, переконань - усього 27\% опитаних. Можливість контролю над рішеннями влади вважають важливими для себе лише $26 \%$ респондентів. Вибірність органів загальнонаціональної влади $\epsilon$ важливою для 11\%, а місцевої влади - для 9\%. Методом інтерв'ю опитано 2012 респондентів за вибіркою, що репрезентує доросле населення України віком від 18 років за такими показниками, як стать, вік, рівень освіти, регіон та тип проживання. Статистична похибка вибірки не перевищує 2.2\%. Спонсором опитування виступили Посольство Швеції в Україні та Шведське агентство з питань міжнародного розвитку і співробітництва [4].

Для вивчення впливу демократичних постулатів на українське суспільство взагалі та на студентську молодь зокрема необхідно розкрити іï (демократії) зміст як сукупності моральних, політичних і правових цінностей.

Передусім, сама демократія $є$ цінністю цивілізованого суспільства. Однак сприйняти іiі як таку можливо лише через іiі зміст, принципи, мету і рівні здійснення. Ці цінності поза людським буттям не існують, вони стають соціальними орієнтирами і принципами поведінки особи та людських спільнот через соціальну свідомість, усвідомлення власних інтересів і здатність захищати та реалізовувати їх. Це означає, що демократія припускає наявність свідомого і активного громадянина, здатного до самоорганізації і самоуправління. Проте це не означає, що інституціоналізація системи демократичних цінностей передбачає їх одновимірне сприйняття всіма членами суспільства. Соціальне розшарування, ідеологічний плюралізм, специфіка психіки людини не можуть забезпечити ідентичне для всіх сприйняття ідеалів демократії. Прагнення до ідентичності прямий шлях до стагнації суспільного розвитку, до диктатури, до автократії. Головним для демократичного розвитку суспільства, забезпечення народовладдя, дотримання і реалізації цінностей демократії є підтримка більшістю її основоположних принципів [2].

До базових соціально-демократичних цінностей ми відносимо права людини, свободу, толерантність, справедливість, авторитет, солідарність та екологічну безпеку. Зміст і сутність зазначених понять достатньо представлені у довідниковій та енциклопедичній літературі.

Основоположною цінністю демократії є пріоритет прав людини щодо прав держави. Демократія як політична система виникла i 
розвивається, передусім, у межах держави, з якою пов'язані іï основні інститути. Тому питання про співвідношення прав людини $\mathrm{i}$ прав держави пов'язане з соціально-правовою природою держави. Так, ідея правової держави передбачає обмеження іiі могутності на користь громадянського суспільства і гарантування пріоритету прав громадян щодо прав держави, а соціальний характер держави спрямований на забезпечення громадянських прав для всіх членів суспільства $[5,94]$. Права і свободи людини $є$ тією цінністю, яка репрезентована в усіх формах і процедурах демократії. Для захисту і реалізації цієї цінності існує демократія. Вона має смисл тільки 3 огляду на те, що кожна людина є носієм певних невідчужуваних прав і свобод, навіть за умови, коли багато хто з громадян нехтує цими правами, зневажає їх. Конституційний правовий порядок $є$ такою системою відносин, за якої всім надається найбільша 3 можливих свобода самодіяльності і самовизначення [6].

Найважливішою цінністю та ідеалом демократії є свобода в усіх iii проявах - особиста, соціально-економічна, правова, політична, мовна, культурна, свобода пересування, врешті-решт. Класичне визначення свободи дав К.Маркс. Він писав: «Свобода - $€$ право робити все те і займатися всім тим, що не шкодить іншому. Межі, в яких кожен може рухатися без шкоди для інших, визначаються законом подібно до того, як кордон двох ланів визначається межевим стовпом» [7, 372].

Г.Тульчинський пише, що 3 достеменною точністю важко визначити сутність цього явища, проте кожен добре відчуває, коли його свобода утискується або зводиться нанівець. Фундаментальне розуміння свободи - це свобода від ланцюгів, від ув'язнення, від поневолення іншими. Той, хто хоче бути вільним, прагне усунути перешкоди; боротися за особисту свободу, тобто покласти край втручанню, експлуатації, поневоленню з боку людей, чиї цілі відрізняються від особистих. Свобода, принаймні у політичному розумінні, пов'язується з відсутністю залякування чи домінування [8].

На думку М.А.Латигіної (і ми з нею погоджуємося), у реальному житті свобода, насамперед політична, підмінюється на диктат більшості, майже на тиранію більшості над меншістю.

Тому єдиним аспектом свободи, який є доступним усім громадянам, залишається право участі у виборах влади. Проте і ця безумовна цінність демократичного суспільства не є необхідною 
для усіх членів суспільства. Значна його частина взагалі ніколи не бере участі у виборах, залишаючись байдужою до інституту політичної свободи у формі волевиявлення на виборах.

Це зумовлено тим, що життєво важливі інтереси людей лежать поза політичним процесом, а їх досягнення жодним чином не пов'язані $з$ демократією. Більша частина людей не бачить особистої користі від реалізації своїх прав і свобод. Більше того, в деяких випадках ця свобода може навіть перешкоджати їх реалізації. I сам механізм підкорення меншості більшості може бути використаний для обмеження індивідуальної свободи. Так сталося, наприклад, в ході демократичної процедури передавання верховної влади у Веймарській республіці Гітлеру.

В цілому політична свобода має невисоку значущість для більшості населення, тому видається сумнівним ставити їі в якості ціннісного обгрунтування соціальної справедливості [3].

Свобода особистості - ключова, визначальна, первинна цінність щодо всіх закономірних правил і свобод. Демократія - форма і процес втілення невідчужуваних прав і свобод громадянина. Це дістає правове закріплення у Конституції і конституційних законах. Конституціоналізм - юридична база демократії. Свобода перебуває у прямій залежності від економічної системи суспільства, таких економічних факторів, як приватна форма власності, вільний ринок і вільна конкуренція. Тільки високий ступінь розвитку цих факторів, тільки економічно розвинуте суспільство може бути гарантією реалізації прав і свобод громадян. Безперечно, можна погодитися 3 тими дослідниками, які визначають прямо пропорційну залежність між часткою сукупного суспільного продукту, що припадає на душу населення, і ступенем розвитку демократії. Дійсно, не існує абсолютних стандартів рівня валового національного продукту на душу населення, але він повинен бути достатньо високим і прогресуючим [3].

Без сумніву, демократія пов'язана 3 процвітанням. Але не процвітання саме по собі, а право процвітати визначає специфіку демократичного суспільства $[9,5]$. Оскільки в сучасному світі більшість людей, не вагаючись, поміняли би політичну свободу, яка є здебільшого є віртуальною декларацією, на стабільне, безпечне i матеріально забезпечене існування, то проголошення свободи як найважливішої загальнолюдської цінності $є$ вельми сумнівним, 3 точки зору обгрунтування демократії в цілому [3]. 
Найгострішою світоглядною проблемою, пов'язаною із демократизацією та «ринковізацією» суспільства, $\epsilon$ все більш очевидне розділення за майновою ознакою на багатих та бідних. Таке соціальне розшарування змінює лице суспільства, внаслідок чого типові та звичні життєві стратегії виявляються шляхами, які ведуть до бідності та соціальної невдачі. Водночас із погіршенням матеріального становища більшості населення у свідомості молоді укорінюються нові стандарти життя, пов'язані із стандартами та стратегіями розвинутих країн світу. Серед молоді відбувається своєрідна зміна орієнтирів, яка супроводжується послабленням мотивації готовності зносити труднощі заради досягнення високих стандартів життя, небажання йти на підвищені навантаження, самопожертву тощо. Гасло «отримати все й одразу» $є$ більш привабливим, ніж багаторічна сумлінна праця заради благополуччя у далекому майбутньому, але й чіткої позиції з приводу майнової нерівності у молоді нема. Спостерігаються дві світоглядні тенденції: одна - досягнути благополуччя, максимально використовуючи можливості ринкової економіки, в тому числі й $з$ тими вадами та перекосами, які у нас зараз $є$. Це досить невелика частка тих, хто має сформовану життєву стратегію, адекватну тим змінам, що відбулися. Інша тенденція молоді люди вважають можливим перерозподіл майна, розглядаючи його як засіб задоволення власних матеріальних потреб, не докладаючи певних зусиль [10].

Поняття свободи в структурі світогляду сучасної молоді набуває також суперечливого значення. Адже, якщо свобода $є$ сутнісною властивістю людини, то такою ж сутнісною й співвимірною масштабам цієї свободи $є$ й відповідальність. Саме через поєднання свободи з відповідальністю перша постає не тільки безконечно жаданою для кожного індивіда, а й тягарем, який треба мати силу винести [11]. Останнє молоддю сприймається далеко неоднозначно. Значна частина молоді відповідальності намагається уникнути.

Для того, щоб визначити межі свободи й відповідальності, повинна існувати якась інстанція, яка не залежала б від чиїхось особистих уявлень і уподобань, від чиєїсь окремої волі чи сваволі. Саме таку інстанцію повинен уособлювати закон, особливою мірою Конституція. Її призначення - чітко визначити принципи соціального співіснування людей у демократичному суспільстві. Непорушність конституційних засад дасть змогу навести соціальний лад і 
взаєморозуміння незалежно від того, який президент стоїть на чолі держави або яка партія здобула більшість у парламенті. Саме тому правова держава повинна визнавати право свободи. Тобто виступати в ролі організації, що підноситься над усіма громадянами, не поглинаючи їх. Відповідно правова держава повинна бути не чим іншим, як системою свободи. Оскільки у правовій державі права i свободи людини оцінюються вище, ніж владні прерогативи, остільки призначенням Конституції $\epsilon$, насамперед, забезпечення вільного життя людини $[12,7]$.

Відповідальність, яка пов'язана із готовністю до дії, стосується й питання справедливості. Уявлення про справедливість для студентської молоді нерозривно пов'язане із співвідношенням особистого та суспільного блага, яке вирішується саме у бік переваги особистісного блага. На жаль, переважна більшість молоді дотепер сприймає державу і суспільство як ресурс для реалізації власних інтересів $[10,87]$. Це $є$ свідченням розбіжності свідомості молоді щодо вибору та відповідальності і, як наслідок, - неповновартісної реалізації нею свободи.

Отже, формування установки на внутрішнє сприйняття «свободи як відповідальності» і «відповідальності як свободи» є завданням стратегічного значення. Найбільш повно воно реалізується через освіту. Освіта в наш час має розглядатись не тільки і не стільки як система набуття знань чи відповідних компетенцій, скільки як механізм внутрішнього ціннісного розвитку особистості, провідними характеристиками якого є свобода і відповідальність.

\section{ЛІТЕРАТУРА}

1. Невмержицький $O$. Поняття демократизації навчально-виховного процесу в сучасному вищому навчальному закладі // Гуманітарний вісник ДВНЗ «Переяслав-Хмельницький державний педагогічний університет імені Григорія Сковороди». Серія: Педагогіка. - Переяслав-Хмельницький : ПХДПУ ім. Г.Сковороди - С. 146-147.

2. Кривега Л.Д. Світоглядні орієнтації особи в умовах трансформації суспільства: автореф. дис. на здобуття наук. ступеня д-ра філос. наук. Харків, 1999. - 30 с.

3. Латигіна Н.А. Цінності та ідеали демократії // Гілея. - Вип. 50 (№ 8) / Національний педагогічний університет ім. М.П.Драгоманова. - К. : 
BIP УAH, 2011. - C.654-661.

4. Бекешкина И. Украинцы превратно понимают демократию [Електронний pecypc] / Режим доступу: http://focus.Ua/politics/110473.

5. Скрипнюк O.B. Соціальна, правова держава в Україні. Проблеми теорії і практики. - К., 2000. -600 с.

6. Горбатенко B. Ценностные аспекты реформирования политической системы Украины // Политический менеджмент. - 2006. - №3. - С.9-12.

7. Маркс К., Енгельс Ф. Вибрані твори, Т.1. - К., 1958. - 670 с.

8. Тульчинский Г.П. О природе свободы // Вопросы философии. - 2006. №4. - C.7-31.

9. Андрєєва Т.О., Стасенко С.О. Світоглядні проблеми сучасної України // Гілея. Історичні науки. Філософські науки. Політичні науки. - К., 2011. C. 256-260.

10. Петров А.В. Ценностные предпочтения молодежи: диагностика и тенденции изменений // Социологические исследования. - 2008. - №2. - С.83-90.

11. Білогур В.С. Формування демократичних цінностей як складової світогляду студентської молоді // Гілея. Історичні науки. Філософські науки. Політичні науки. - К., 2011. - Вип. 53 (№ 10). - С.373-378.

12. Новожилов Б.В. Роль цінностей демократичного суспільства у формуванні політичного іміджу лідера // Гілея. Історичні науки. Філософські науки. Політичні науки. - К., 2012. - Вип. 63 (№8). - С. 563-569.

Шелюк Л.М. Освіта в системі формування демократичних орієнтаиій молодi.

У статті здійснюється аналіз освіти, як одного з основних соціальних інститутів формування демократичних цінностей і світогляду сучасної молоді; вищий навчальний заклад $\epsilon$ для неї ще й середовищем потенційної реалізації демократичних принципів мислення. Тому саме ВНЗ виконують функції громадянської освіти, прищеплюючи студентам демократичні якості - єдність, солідарність, толерантність тощо. Звертається увага на те, що система вищої освіти є важливою ланкою запровадження демократичних тенденцій у студентському середовищі та у суспільстві. Найбільш важливою цінністю та ідеалом демократії є свобода як ключова, визначальна риса громадянина. Свобода, у свою чергу, є певною властивістю людини, яка співвимірна з відповідальністю. В статті розкривається вплив демократичних чинників на студентську молодь, на формування у неї моральних, політичних і правових цінностей.

Ключові слова: людина, освіта, культура, виховання, світогляд, демократичні цінності, свобода. 
Шелюк Л.Н. Образование в системе формирования демократических ориентаций молодежи.

В статье осуществляется анализ образования как одного из основных социальных институтов формирования демократических ценностей и мировоззрения современной молодежи; высшее учебное заведение является для нее еще и средой потенциальной реализации демократических принципов мышления. Поэтому именно вузы выполняют функции гражданского образования, прививая студентам демократические качества единство, солидарность, толерантность и т.д. Обращается внимание на то, что система высшего образования является важнейшим звеном внедрения демократических тенденций в студенческой среде и в обществе. Наиболее важной ценностью и идеалом демократии есть свобода как ключевая, определяющая черта гражданина. Свобода, в свою очередь, является определенным свойством человека, соизмеримая с ответственностью. В статье раскрывается влияние демократических факторов на студенческую молодежь, на формирование у нее моральных, политических и правовых ценностей.

Ключевые слова: человек, образование, культура, воспитание, мировоззрение, демократические ценности, свобода.

\section{Sheliuk L. Education in the system of forming democratic orientations of the youth.}

Analysis of education as one of the main social institutions of forming democratic values and worldview of modern youth was carried out in the paper; higher educational institution is an environment of potential implementation of democratic principles of thinking for it. Therefore HEI often carries out functions of public education, instilling in students various democratic qualities of unity, solidarity, tolerance and so on. Attention was paid to the formation of value civic base of human worldview, where principal and main institution is a system of higher education, which is the main feature of implementation of democratic tendencies among students and in community. The most important value and ideal of democracy is freedom as a key, defining, primary feature of a citizen on all regular rules and freedoms. Freedom in turn is a certain property of a person which is equal to responsibility, where the latter is perceived in an effort to avoid and ambiguity. In the paper, influence of democratic factors on student youth was revealed in a view of formation of its moral, political and legal values.

Key words: human, education, culture, upbringing, worldview, democratic values, freedom. 